\title{
Analysis on the Democratic Significance of the Political Participation of Non-profit Organizations in China
}

\author{
Tiantian Zhao \\ Southwest University for Nationalities \\ E-mail: 835436663@qq.com
}

\begin{abstract}
The non-profit organizations, as the main part of the political participation of our country, shall combine with the development of the grass-root democracy. The political participation of non-profit organizations in the democratic trend is decisive. It has become an important content in China's democratic political construction. Based on our current social and political realities, the paper has analyzed the political participation of non-profit organizations in the view of the development of political civilization, and discussed its democratic significance in building democratic politics with Chinese characteristics, and tried to provide some referential thoughts to improve the political participation of our nonprofit organizations.
\end{abstract}

Keywords-non-profit organizations; political participation; democracy

\section{INTRODUCTION}

Democracy is a major trend in the development of the world. In the development of democratic society, the nonprofit organization is an indispensable social force. Nonprofit organization is a faithful guardian to national democracy and social value. Its booming development reflects citizen vitality of a society and represents the diversity and openness of a society. Its widening participation is the basic content of modern political development, with a further deepening trend. Non-profit organizations, as a major force in the impact of China's society, can promote citizens to enter into the process of political life system. It has an important significance for widening the channels of grassroots democracy, enhancing the political civilization of the society, and maintaining social harmony and stability. In the current social transformation, with the deepening development of the transfer of Chinese governments' functions, and the political and economic system reform, the non-profit organization, as an important social force, has gradually revealed its significance. Its political participation has become an important social and political phenomenon. To strengthen the construction of non-profit organizations, and guide the orderly participation of citizens in social and political construction, is an important way to protect the democratic

[Fund program] This program is funded by the graduates' innovative $r$ esearch projects of the Southwest University for Nationalities (Analysis on the Significance of Political Participation of Non-

Profit Organization in China CX2016SP43). rights of citizens, is the most direct and effective way to arouse the masses to actively participate in the construction of a harmonious society. How to play its democratic significance in a higher degree in the political participation process and effectively promote the construction of national political civilization is an important issue of the party and the government in China.

\section{THE CONNOTATION AND CHARACTERISTICS OF THE POLITICAL PARTICIPATION OF NON-PROFIT ORGANIZATIONS}

The non-profit organizations refer to non-governmental social organizations that are not for making profit and have formal organization form, with certain autonomy, voluntariness, public benefit or mutual benefit. In 1980s, the transformation of the economic system and government functions provide an opportunity for the rapid development of the non-profit organizations. According to the relationship between nonprofit organization and its service object, we can divide non-profit organizations into mutual-benefit nonprofit organizations and the public-benefit non-profit organizations. The service object of the mutual-benefit nonprofit organization is limited to the members of the organization, and the work of the organization is closely around the interests of the members of the organization. The later represents the interests of eight major groups including workers, the youth, women and etc., as well as all kinds of trade associations and academic societies. The political participation of non-profit organization refers to the activities of the non-profit organizations trying to influence the governments' policy process. The service objects of publicbenefit non-profit organization are some special groups outside the organization. These organizations may provide public goods and other services, but it is not allowed for them to serve themselves. In China, the well-known publicbenefit non-profit organizations are the China Youth Development Foundation initiating and implementing "Hope Project", the Chinese Children and Teenagers Foundation organizing the "Spring Bud Plan", China Foundation for Poverty Alleviation cooperating with governments' poverty alleviation work, Comprehensive Charity Organization China Charity Federation and so on.

The political participation of non-profit organization refers to the activities of the non-profit organizations trying 
to influence governments' policy process. The government mentioned in the paper refers to the government in a broad sense, including the ruling party, the National People's Congress, the government and the CPPCC. Policy process refers to the process of public policy formulation, implementation, evaluation and termination. Non-profit organizations file administrative review and lawsuit by providing relevant information, private contact and direct representation, participate in the hearing, organize academic conferences and forums, and publish journals, magazines and newspapers. They can participate in politics by alliance lobbying, organizing joint activities, using news media and the international force to protest violence activities and other means. Here, the basic content of the political participation of non-profit organization is summarized as the promotion of interest expression, participation in policy formulation, participation in policy supervision and promotion of grassroots autonomy.

The main parts of the political participation are different, and the characteristics of their participation are also different. As a special product of the modern economic and political system, the non-profit organization is becoming the important power of building democratic politics and promoting social justice, and it plays a unique role in social and political life. Specifically, the political participation of non-profit organization has the following characteristics. First, the purpose is not for profit. The political participation of the non-profit organization is not for the benefit of the organization itself, and the income cannot be allocated among the members. The income can be used to carry out the activities of the organization in line with articles of association. However it is necessary to point out that the goal of political participation of non-profit organizations is to maintain the interests of its representative groups. The interests of these groups may conform to the social public interests, or conflict with the social public interests. Second, participation issues are extensive. The activities fields of non-profit organizations in China are mainly concentrated in economy, technology, environmental protection, humanitarian aid, academic exchange, sports, religion, charity, public health, education, social security and poverty alleviation and etc. Their concerns usually are the fields that governments are not willing or not able to cope. Third, the participation behavior is open and initiative. They can participate in the politics by directly lobbying the government, and using public opinion and modern network technology, and learning from social forces and international resources. And the goal and behavior of their political participation are open and transparent. The more open and transparent, the bigger the social influence is and the better the participation effect. Finally, the participation objects are diversified and closely related to the intellectuals. The nonprofit organizations pay more attention to the political participation of the NPC and the CPPCC, and the intellectuals actively participate in the volunteer service and the public benefit undertakings, providing professional knowledge and information. They are not only the active participants of the non-profit organizations, but also the leaders and the backbone of the non-profit organizations.
III. The DEMOCRATIC SignificANCE OF THE POLITICAL PARTICIPATION OF NON-PROFIT ORGANIZATIONS IN CHINA

From the structure of the political civilization, political civilization can be divided into political consciousness civilization, political system civilization and political behavior civilization. The soul of the political consciousness civilization is "substantial". The political system civilization is "balanced". The political behavior civilization is "orderly", The integration of these three characteristics is the highest state of human social and political civilization. And for the construction of human democracy, these three characteristics separately are the inner souls of democratic consciousness, democratic system and democratic behavior, which is the highest achievement in the construction of democracy. As a social intermediary organization between government and citizen, the non-profit organization has the realistic democratic significance: it is helpful to cultivating the "substantial" democratic consciousness in the society, and forming the "balanced" democracy system and exercising the citizens' "orderly" democratic behavior.

\section{A. Helpful to Cultivating the "Substantial" Democratic Consciousness in the Society}

Democratic consciousness refers to people's concept reflection on the national democratic politics, democratic rights and legal system in a certain economic system and political system. As the subjective condition of democracy, democratic consciousness is the spiritual core of democratic system, it is because the democratic system is established and perfected by people. So the premise for the smooth running of democratic system is that "the spirit of democracy is rooted in the hearts of every citizen, and is internalized into the unique characteristics of personality and thinking habits, and promotes the majority of members of society to act according to this spirit". Nonprofit organizations, as the supervisor of government power and the cultivator of democracy value, have formed the basic political role of the political participation. The non-profit organizations have provided provides a self-organized space for people's freedom of association. With the public interest as the goal, these organizations protect the interests of the whole human. They arouse the public consciousness of the public and cultivate the public with correct view of political participation through organizing activities, and thus influence the democratization and openness of public decision-making of the government. As a social group of voluntary participation, the non-profit organizations generally do not take the vertical hierarchical and centralized leadership system, but the decentralized, non-hierarchical network organization system. People in the organization are equal, with mutual support and mutual trust. The activities of non-profit organizations are also carried out by a noncompulsory democratic way. This characteristic makes the concept of democracy and equality gradually infiltrated into the daily behavior of citizens, which is conducive to the cultivation of the democratic consciousness of modern citizens. 


\section{B. Helpful to Forming the "Balanced" Basic Democratic System}

The construction of democratic politics needs to seek a balance between the state and the society, so that it can form a benign interactive relationship between the state and society. In the contemporary Chinese society, we should seek and construct such a balanced relationship, and think from the national level, and explore from the social view in order to determine the lever of balanced social forces. Nonprofit organization can act as the lever. The non-profit organization's prosperity can form a kind of organized power restricting power, and help the construction of "the power restriction system by society. Non-profit organizations have irreplaceable advantages in the interests of the expression compared with other organizations. They are important platforms to reasonably express interest appeals of different groups, safeguard their interests, realize their wills, integrate the interests of the community, and participate in grassroots democracy. They can mobilize social force and integrate and express interests of the public through a variety of ways and methods, forming a strong pressure of public opinion and the force of public opinion, and thus effectively resist the illegal behaviors and misconducts of grass-roots government or its staff against the interests of citizens and correct offside and omission of government power and restrict the power of grass-root government from different areas. On the whole, the non-profit organizations are the important carriers of citizen participation in grassroots democracy in our country, and its political participation is conducive to the formation of a "balanced" grass-roots democracy system.

\section{Helpful to Exercising Citizens, "Orderly" Democratic Behavior}

From the operational level, the meaning of democracy is the procedures, techniques and methods of the political participation. The development of non-profit organizations is not only related to the construction of democratic system, but also the study of the democratic ability of citizens. As a selfmanagement, self-serving social organization, non-profit organizations can provide an operational platform for the democratic practice of citizens. They play a good role in helping citizen cultivate "orderly" democratic participation behavior. On the one hand, the non-profit organizations can transform the citizens' scattered and single political participation behaviors into a community participation behavior with certain procedure and organizational norms. Non-profit organization can propaganda democratic knowledge, democratic procedures and etc. in organizing citizens to participate political practice to restrict and regulate their political participation behavior and avoid isolated, spontaneous and impetuous political participation, and make it develop toward a standardized, procedural, and rational direction. On the other hand, the non-profit organizations in the enjoyment of the protection of the organizations, shall accept the organization's autonomy norms, so as to ensure its authority and consistency. Through the internal democratic management of non-profit organizations, organization members can not only experience and understand democracy personally, but also help exercise the democratic operation skills of members in practice and accumulate democratic experience, and be accustomed to use orderly democratic behaviors to solve real social problems.

\section{TO PROMOTE AND IMPROVE THE POLITICAL}

\section{PARTICIPATION OF NON-PROFIT ORGANIZATIONS IN CHINA}

The political participation of the non-profit organizations in our country expands the grass-root democracy, which is helpful to promoting the construction of democratic politics. Although the development time of our non-profit organizations is short, and there are some deficiencies in its economic and political environment and the internal governance, the democratic significance of political participation is indelible. As long as we strengthen the guidance, and constantly promote and improve the political participation of non-profit organizations in China, the development of democratic politics with Chinese characteristics, and the construction of political civilization will play an irreplaceable role.

\section{A. To Transform Ideas of the Government and Enhance the Political Function of the Non-Profit Organizations}

A lot of non-profit organizations in China are established and developed through the acquisition of top-down resources, including political resources, and thus they are heavily dependent on the government in the concept, organization, system, activities and other aspects. Today, there are still many ideas of "official standard". The government neglect people's sufferings and does not very accept these non-profit organizations. The government thinks all non-profit and nongovernment organizations are not organized, of indiscipline and even against the government. The governmentdominated mode, the government has undertaken all social public affairs, and other organizations are in a subordinate position. With the transformation of economic development mode, the transformation of government functions, the establishment of civil society, the status and effect of nonprofit organizations is improved in the society increasingly. The idea of "official standard" is becoming more and more incompatible with modern society. Therefore, government capacity building should be a priority, and the government should also return some powers to non-profit organizations, and thus enhance the political function of non-profit organization. We should gradually improve the government's policy implementation ability, regulatory ability, service ability, etc. through transforming the concept of the government and making management innovation. This is also conducive to the construction of service-oriented government. The government continues to improve its construction of responsibility, and introduce social forces in an appropriate social scope, so that they can share certain public management affairs for the government.

\section{B. To Strengthen and Improve the Relevant Legislation and System Construction}

First, we should regulate the political behavior of nonprofit organizations in system. Market economy is a legal economy. The non-profit organizations can form autonomous norms inside as long as they act according to laws, regulations and rules, and develop the autonomy and 
self-discipline consciousness of the members, thus establish the spirit of democracy and legal system in the whole society. But now, the government lacks strict norms in the administration of non-profit organizations, and the legal degree is not high in our country, resulting in deviations of purpose and violation of laws or disciplines. It has seriously affected the normal operation and healthy development of non-profit organizations. Therefore, the government should make clear legal provisions on the nature, status, function, rights and obligations of the non-profit organizations according to the actual situation of the non-profit organizations in China.

And we can gradually form supporting legal system of different levels, and have laws to abide by in the development and management of non-profit organizations. As a result, we can provide stable and adequate space for existence and growth of non-profit organizations, strengthen the non-profit organizations' autonomy and self-discipline consciousness and the spirit of democracy and legal system, forming the vanguard force to promote the development of civil society. At the same time, the government shall increase its support in the capital, human resources, policies and other aspects, continue to improve the supervision mechanism, and strengthen the organization's autonomy and the reasonable construction of the accountability mechanism.

\section{To Strengthen Self-Management Ability of Non-Profit Organizations}

In addition to our efforts in above areas, we shall rely on their own development to improve the political participation of the non-profit organizations in China. Only the strength of the organization has been enhanced, and the management system has been improved, their political participation ability can be improved. The non-profit organizations should not only improve the satisfaction of the government, but also improve the satisfaction of the public. In other words, they should improve social credibility. They should improve self cognition and quality of members, improve the internal governance structure, strengthen members' civic awareness and political awareness, and cultivation and training of political skills. What's more, they shall increase the understanding of the members on national policy process and related laws and regulations and policies and thus improve their credibility. At the same time, the non-profit organizations should strengthen the communication with their representative classes, and increase the representation of the interests. They should enhance their political influence, and improve the "bargaining" ability among the government, enterprises and donation institutions. To this end, they should seriously investigate and study policy voice and interest requirements of their representative classes, and dare to speak for them.

\section{REFERENCES}

[1] Wang Ming, China's Non-profit Organizations: Definition, Development and Policy Recommendations. Social Changes and Non-profit Organizations in the Globalization. Shanghai: Shanghai People's Publishing House, 2003. 265.
[2] Cheng Zhigang, Zhou Wei. Problems and Countermeasures of NPO's Political Participation in China. Search, 2005, 10.

[3] Yu Chongsheng. The Theory of Political Civilization. Wuhan: Wuhan University Press, 2003: 149.

[4] Ma Baobin, Ma Zhenqing. The Political Participation of Chinese Society Groups in the New Period. Chinese Politics, 2005 (12): 49-55.

[5] Zhou Wei. Analysis on Characteristics and Approaches of Political Participation of China's NPO. Journal of Central South University of Forestry and Technology, 2008 (2). 